\title{
Studies on solid matrix priming of seeds in bitter gourd (Momordica charantia L.)
}

\author{
Rajesh Kanwar $^{1 *}$ and D. K. Mehta ${ }^{2}$ \\ ${ }^{1}$ Department of Seed Science \& Technology, College of Horticulture, Dr YS Parmar University of Horticulture and \\ Forestry, Nauni, Solan- 173 230, (Himachal Pradesh), INDIA \\ ${ }^{2}$ Department of Vegetable Science, College of Horticulture, Dr YS Parmar University of Horticulture and Forestry, \\ Nauni, Solan- 173 230, (Himachal Pradesh), INDIA \\ *Corresponding author. E-mail: intangiblekanwar07@gmail.com
}

Received: July 14, 2016; Revised received: November 19, 2016; Accepted: February 6, 2017

\begin{abstract}
A study was carried out to evaluate the effect of solid matrix priming of seeds on emergence (\%), growth and fruit yield characters of bitter gourd (Momordica charantia L.) cultivar 'Solan Hara'. The Experiment comprised of two vigour groups of seeds viz., ' $V_{1}$ ' (High vigour seeds) and ' $V_{2}$ ' (72 hours accelerated aged seeds/low vigour seeds) and five seed priming treatments viz., ' $\mathrm{P}_{1}$ ' (Solid matrix priming with Cocopeat), ' $\mathrm{P}_{2}$ ' (Solid matrix priming with Perlite), ' $\mathrm{P}_{3}$ ' (Solid matrix priming with Vermiculite), ' $\mathrm{P}_{4}$ ' (Seed soaking in water), ' $\mathrm{P}_{5}$ ' (Control -Without treatment). Investigation proved that low vigour seeds were inferior in respect of high vigour seeds in terms of seed physiological quality, emergence, growth and yield characteristics. Seed priming with Perlite for 72 hours proved its potential over other priming treatments, seed soaking and control (non-primed seeds) in both high vigour and low vigour seeds for agronomic attributes under study. High vigour seeds primed with Perlite ' $\mathrm{V}_{1} \mathrm{P}_{2}$ ' was found to be the best treatment for most of the traits understudy recording highest total field emergence $(76.60 \%)$, fruit yield per plot $(16.12 \mathrm{Kg})$ and per hectare $(250.35 \mathrm{q})$. Similarly, Low vigour seeds primed with Perlite also recorded enhanced and improved total field emergence $(73.83 \%)$ fruit yield per plot $(9.28 \mathrm{Kg})$ and per hectare $(143.26 \mathrm{q})$ compared to other low vigour treated and non treated seeds. From the present investigation it was inferred that that the extent of improvement w.r.t. attributes studied was more in low vigour seeds $\left(V_{2}\right)$ and seed priming with solid matrix carrier 'Perlite' can be used as a beneficial pre-sowing treatment to enhance the seedling emergence, growth and yield characteristics in bitter gourd.
\end{abstract}

Keywords: Emergence Percentage, Fruit yield, Growth, Solid Matrix Priming

\section{INTRODUCTION}

Momordica charantia L. called bitter melon or bitter gourd in English, is a tropical and subtropical vine of the family Cucurbitaceae, widely grown in Asia, Africa and Caribbean for its edible fruit. The plant as a whole has many medicinal uses. It is antihelmintic, antimalarial, antiviral, cardioprotective and anticancerous. In Himachal Pradesh, to get crop early in the season, the seeds need to be sown in the month of March - April. Similarly in North Western Indian plains bitter gourd is generally sown early in the months of December or January so that crop gets ready for harvesting in March - April. The major problem during this period is poor and slow emergence of bitter gourd seedlings due to prevailing sub optimal temperatures. The germination of the bitter gourd seed is adversely hampered at sub optimal temperature i.e. below $18^{\circ} \mathrm{C}$. In addition to this thick seed coat enclosing embryo, affect germination by imposing mechanical restriction on embryo growth. Another critical factor affecting physiological aspect of seed is the vigour of the seed lot. Low vigour of seeds contributes to reduced emergence, growth, yield and storage attribute. This problem of poor or slow seed germination can be solved through many techniques and one of them is seed priming (Pandita and Nagarajan, 2004).

Solid matrix priming is a pre sowing controlled seed hydration treatment in which seeds are mixed with the solid carrier with low matric potential that allows them to imbibe water and go through first stage of germination but does not permit radical protrusion through the seed coat. After priming, the seeds are dried back to enable normal handling, storage and planting (Mehta et al., 2013). The key processes involved in seed priming are, the early onset of RNA, protein synthesis and polyribosome formation. The activities of many enzymes involved in mobilization of storage reserves are triggered. During seed priming, the water content of the seed increases upto 35 to 40 percent of its weight, enough to activate the biochemical events, advancing seed germination processes without radical emergence. The product of these changes persist following desiccation and are available on re-imbibition of water during seed sowing, enabling completion of seed germination rapidly, led to an uniform crop stand and synchronized flowering / fruiting. Under invigoration, 
metabolic repair processes in deteriorated seeds occur before onset of seed germination process (Varier et al., 2010).

The growing concept of precision planting demand seeds with high physiological returns when sown in the fields with various growing uncertainties. Seed being a living entity, its deterioration in quality occurs with the advancement in ageing which is natural, inevitable, irreversible and continuous process. Yeh and Sung (2008) postulated that during ageing, unsaturated fatty acid components of lipid membranes i.e. phospholipids are converted into free radicals and cytotoxic aldehydes by the reaction with atmospheric oxygen and lipoxygenase activity resulting in rapid deterioration. The carry over seeds in the market with reduced germination potential are excellent subject material whose metabolic and physiological inefficiency to grow can be rejuvenated through a potent technique called seed priming. Keeping in view the above facts, the present investigation was undertaken with the objective to study the effect of seed priming on germination, vigour, growth and yield of bitter gourd (Momordica charantia L.).

\section{MATERIALS AND METHODS}

The present study was conducted at Khaltoo experimental farm of the Department of Seed Science and Technology, Dr. Y.S. Parmar University of Horticulture and Forestry, Nauni, Solan, H.P. The treatment combinations comprised of two vigour groups of seeds and five seed priming treatments (Table 1). Accelerated ageing of seeds was achieved by placing the seeds in dessicator at a temperature of $40^{\circ} \mathrm{C}$ and nearly at 90 per cent Relative Humidity for $72 \mathrm{hrs}$. For solid matrix priming sample of 100 grams of bitter gourd seeds from two seed lots of different vigour groups per treatment were put in separate containers containing carrier. Seeds : solid matrix : water was mixed in the ratio of 1:2:1 for each treatment and shaked well so that seeds and priming media are mixed properly. Priming was done for 72 hours at $20^{\circ} \mathrm{C}$ and 90 per cent Relative Humidity and the containers were shaked manually after every 3-4 hours for proper aeration. After seed priming for 72 hours, the solid matrix was separated from the seeds through sieving and seeds were washed with tap water 3-4 times. In case of seed soaking, the seeds were simply soaked in water for 24 hours as done by the farmers. The primed and soaked seeds were then dried completely in shade to 8 per cent moisture content. Unprimed seeds served as control. The experiment was laid out in Randomized Block Design (factorial) with ten treatment combinations replicated thrice. The size of the plot was $2.7 \mathrm{~m} \times 1.8 \mathrm{~m}$. The observations on days to 50 per cent emergence, total emergence (\%), plant height 30 days after sowing (cm), days to first female flower appearance, node at which first female flower appear (number), days to first picking, harvest duration (days), vine length $(\mathrm{cm})$, fruit Length $(\mathrm{cm})$, fruit diameter $(\mathrm{cm})$, fruit weight $(\mathrm{g})$, number of fruits per plant, fruit yield per plant $(\mathrm{kg})$, fruit yield per plot $(\mathrm{kg})$ and fruit yield per hectare $(\mathrm{q})$ were taken on five randomly selected plants from each replication.

Statistical analysis: The statistical analysis was done as per design of the experiment as suggested by Gomez and Gomez (1984).

\section{RESULTS AND DISCUSSION}

Days to $50 \%$ emergence is an important character and an indicator of getting early and higher yields in bitter

Table 1. Detail of treatments used for the study

\begin{tabular}{lcl}
\hline S. N. & $\begin{array}{c}\text { Treatment } \\
\text { combination }\end{array}$ & Treatment details \\
\hline 1 & $\mathrm{~V}_{1} \mathrm{P}_{1}$ & High vigour seeds and Solid matrix priming with Cocopeat \\
2 & $\mathrm{~V}_{1} \mathrm{P}_{2}$ & High vigour seeds and Solid matrix priming with Perlite \\
3 & $\mathrm{~V}_{1} \mathrm{P}_{3}$ & High vigour seeds and Solid matrix priming with Vermiculite \\
4 & $\mathrm{~V}_{1} \mathrm{P}_{4}$ & High vigour seeds and Seed soaking in water \\
5 & $\mathrm{~V}_{1} \mathrm{P}_{5}$ & High vigour seeds and Control -Without treatment \\
6 & $\mathrm{~V}_{2} \mathrm{P}_{1}$ & 72 hours accelerated aged seeds/low vigour seeds and Solid matrix priming with \\
7 & $\mathrm{~V}_{2} \mathrm{P}_{2}$ & Cocopeat \\
& & Perlite \\
8 & $\mathrm{~V}_{2} \mathrm{P}_{3}$ & 72 hours accelerated aged seeds/low vigour seeds and Solid matrix priming with \\
& & Vermiculite \\
9 & $\mathrm{~V}_{2} \mathrm{P}_{4}$ & 72 hours accelerated aged seeds/low vigour seeds and Seed soaking in water \\
10 & $\mathrm{~V}_{2} \mathrm{P}_{5}$ & 72 hours accelerated aged seeds/low vigour seeds and Control -Without treatment \\
\hline
\end{tabular}


Rajesh Kanwar and D. K. Mehta / J. Appl. \& Nat. Sci. 9 (1): 395 - 401 (2017)

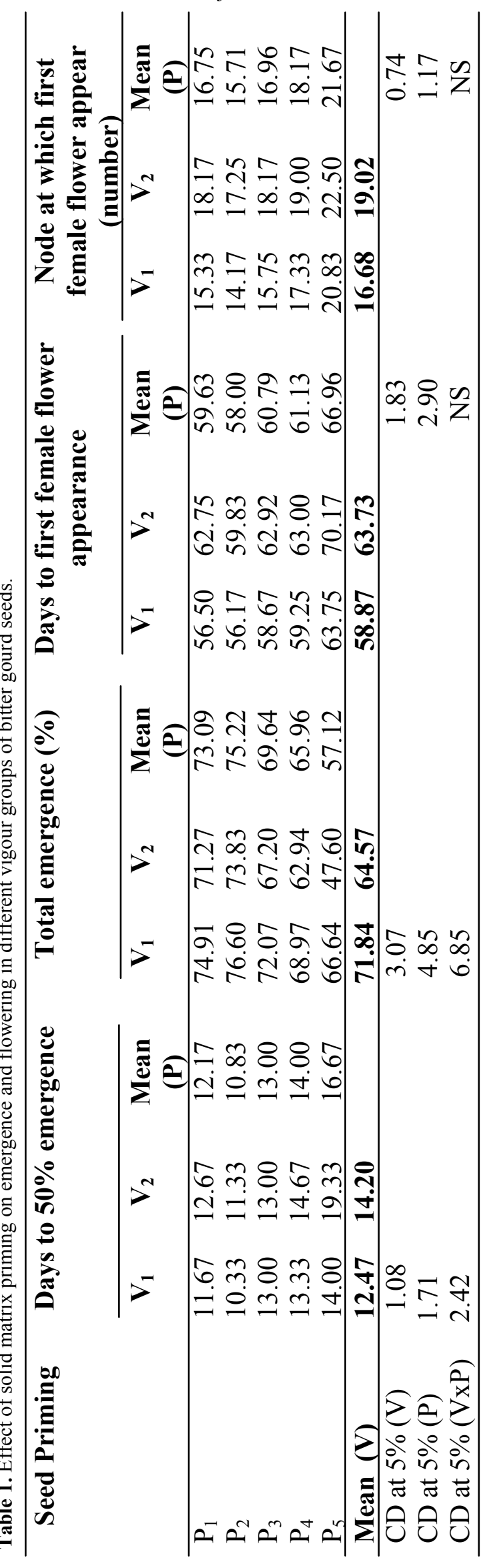

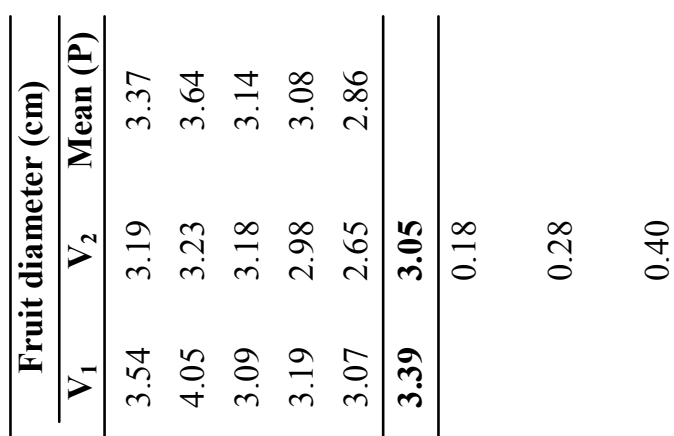

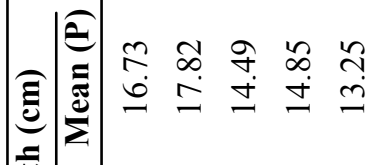

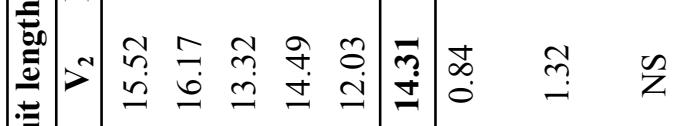

承

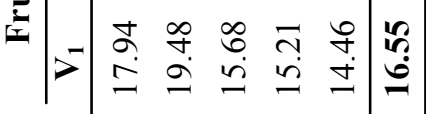

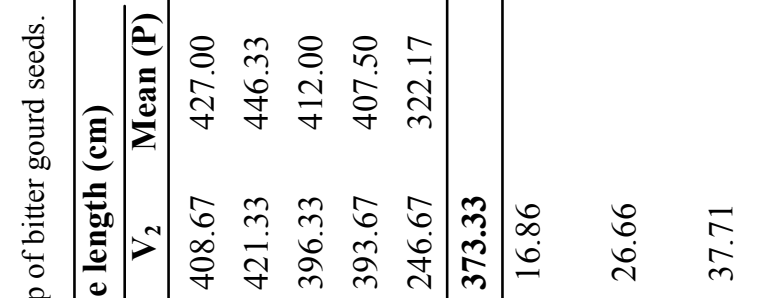

言

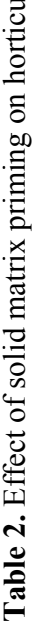


gourd. Days to 50 per cent emergence increased from 12.47 days to 14.20 days with decrease in vigour level from high level $\left(\mathrm{V}_{1}\right)$ to low level $\left(\mathrm{V}_{2}\right)$. There was considerable increase in days to 50 per cent emergence in low vigour seeds or accelerated aged seeds $\left(\mathrm{V}_{2}\right)$. The main cause can be the deterioration of the seeds due to accelerated ageing. Saha and Sultana (2008) studied the effect of seed ageing on stand establishment and growth in three soyabean varieties. The seeds were treated to four different ageing levels viz., 20,12, 8 and 2 months. The results revealed that seed germination and field emergence percentage decreased with increasing seed age in all the soybean varieties. All the priming treatments significantly reduced days to $50 \%$ emergence irrespective of vigour levels. The early emergence of 10.83 days was recorded in Perlite primed seeds $\left(\mathrm{P}_{2}\right)$ and delayed emergence of 16.67 days was recorded in Control $\left(\mathrm{P}_{5}\right)$. Study of interaction effects between vigour levels and priming treatments revealed the significant reduction in days to $50 \%$ emergence over control in both high vigour and low vigour levels respectively. In high vigour seeds primed with Perlite $\left(\mathrm{V}_{1} \mathrm{P}_{2}\right) 50 \%$ emergence occurred 4 days earlier to Control $\left(\mathrm{V}_{1} \mathrm{P}_{5}\right)$. On the other hand in low vigour seeds primed with Perlite $\left(\mathrm{V}_{2} \mathrm{P}_{2}\right) \quad 50 \%$ emergence occurred 8 days earlier to Control $\left(\mathrm{V}_{2} \mathrm{P}_{5}\right)$. The possible reason why reduction in days to $50 \%$ emergence was more in low vigour seeds compared to high vigour seeds could be that low vigour seeds due to accelerated ageing might have undergone severe metabolic damage and loss of stored food reserves. As a result Perlite treated low vigour seeds were able to resume the growth at the faster pace compared to untreated low vigour seeds. Thereby creating a difference of 8 days. The early emergence of the primed seeds may be due to the completion of pre-germination metabolic activities making the seeds ready for radicle protrusion and the primed seed germinated soon after planting as compared to untreated dry seeds (Arif, 2005). These positive effects are probably due to the stimulatory effects of priming on the early stages of germination process by mediation of cell division in germinating seeds (Sivritepe et al., 2003 and Hassanpouraghdam et al., 2009).

Total emergence (\%) is an important character as optimum plant population is a pre requisite for the efficient use of resources and eventually increased yield. Total emergence per cent reduced linearly from 71.84 per cent to 64.57 per cent with decrease in vigour level from high level $\left(\mathrm{V}_{1}\right)$ to low level $\left(\mathrm{V}_{2}\right)$ (Table 2). There was considerable reduction in total emergence in low vigour seeds $\left(\mathrm{V}_{2}\right)$. Such decline in field emergence due to reduced germination and seedling vigour as manifested through ageing was also observed by Basra et al., (2003) in upland cotton (Gossypium hirsutum L.) cv. NIAB-78. The authors reported that reduction in emergence percentage and vigour might be due to membrane disintegration and inactivation of enzymatic systems of seed due to lipid peroxidation and increase in free fat acidity during ageing. All the priming treatments significantly enhanced emergence percentage irrespective of vigour levels. The maximum emergence was recorded in Perlite primed seeds $\left(\mathrm{P}_{2}\right)$ and minimum emergence was observed in Control i.e. unprimed seeds $\left(\mathrm{P}_{5}\right)$. The study of interaction effects between vigour levels and priming treatments revealed the significant improvement in emergence percentage over control in both high vigour and low vigour levels respectively. High vigour seeds primed with Perlite $\left(\mathrm{V}_{1} \mathrm{P}_{2}\right)$ showed 9.96 percent increase in emergence over control $\left(\mathrm{V}_{1} \mathrm{P}_{5}\right)$. Moreover low vigour seeds primed with Perlite $\left(\mathrm{V}_{2} \mathrm{P}_{2}\right)$ observed 26.23 per cent increase over Control $\left(\mathrm{V}_{2} \mathrm{P}_{5}\right)$. The improvement in low vigour seeds was more compared to high vigour seeds. This could be due to the fact that accelerated aged low vigour seeds were more prone to deterioration in the field condition. Priming induces a range of biochemical changes in the seed that are required to start the germination process like breaking of dormancy, hydrolysis or metabolism of the inhibitors and enzymes activation (Aziza et al., 2004). Some or all processes that precede the germination are triggered by priming and persist following the re-desiccation of seeds (Asgedom and Becker, 2001). The results are in line with the findings of Ghassemi et al. (2008) who studied the effect of hydro and osmopriming (PEG6000 at $-0.8 \mathrm{MPa}$ ) on seed germination and field emergence of lentil and concluded that hydropriming can be used as simplest method for improving seed germination and seedling emergence of lentil in field conditions.

Days to first female flower appearance is an important indicator of getting early yields in bitter gourd. Days to first female flower appearance differed significantly between high and low vigour seeds. First female flower appeared early (58.87days) in high vigour seeds $\left(\mathrm{V}_{1}\right)$ and this phenomenon was delayed (63.73 days) in low vigour seeds $\left(\mathrm{V}_{2}\right)$. Delayed flowering in low vigour seeds might be due to low initial seedling vigour and productivity status of aged seeds. These results are in accordance with the findings of Sandhyarani (2002) in cotton and Verma et al. (2006) in greengram. The data revealed that seed priming with Perlite $\left(\mathrm{P}_{2}\right)$ exhibited best results recording 58.00 days to first female flower appearance while Control $\left(\mathrm{P}_{5}\right)$ recorded 66.96 days to first female flower appearance which was poorest of all the treatments. These results were in agreement with the findings of Mauromicale et al., (2000) who reported that plants of summer squash from primed seeds exhibited advancement of 2.5 to 7.5 days in anthesis of first female flower. The results are further endorsed by Harris et al., (2001) who reported direct benefits of seed priming in all crops include fast- 


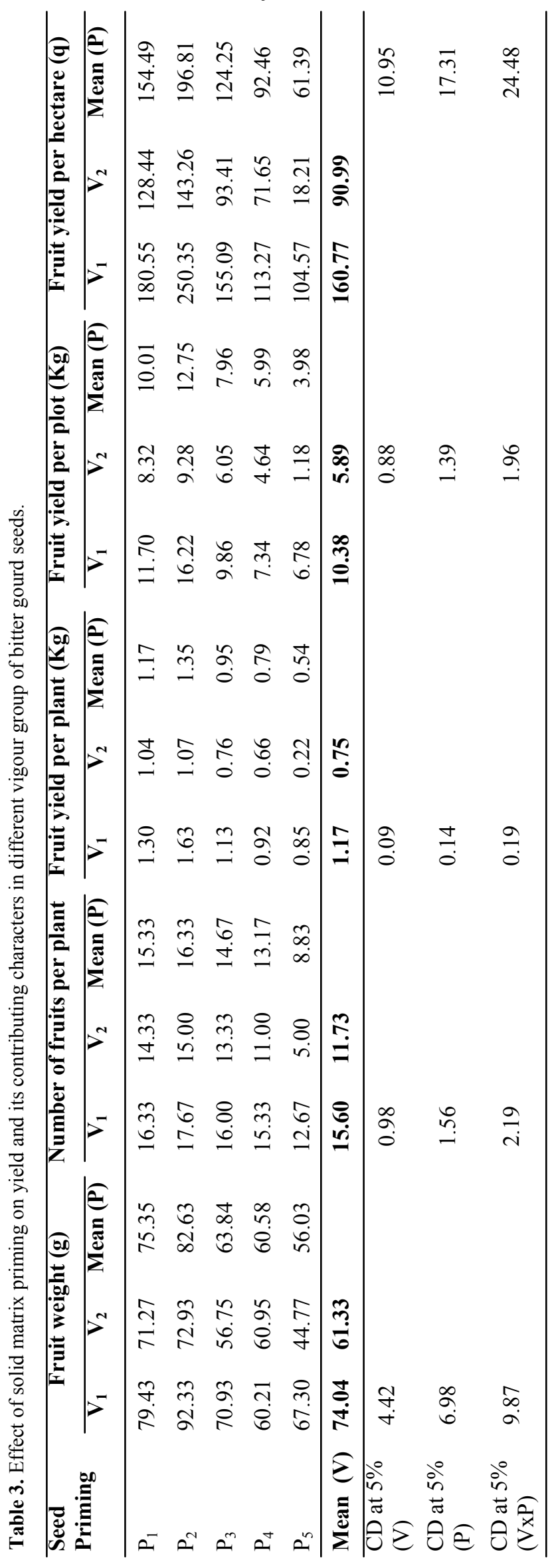

er emergence, more vigorous plants, earlier flowering and early harvest. Interaction effects between vigour levels and priming treatments were found to be non significant for days to first female flower appearance.

Days to first picking is an indicator of maturity period in bitter gourd. Early maturity is desirable which always fetches good returns to the growers. The data revealed that fruits were ready for marketing in 80.38 days in high vigour level $\left(\mathrm{V}_{1}\right)$ and in 83.30 days in low vigour level $\left(\mathrm{V}_{2}\right)$. This is on account of delayed flowering in low vigour seeds as a result of low initial seedling vigour. The data showed the best result in seeds primed with Perlite $\left(\mathrm{P}_{2}\right)$ recording 79.08 days to first picking while Control $\left(\mathrm{P}_{5}\right)$ stood the poorest observing 87.71days to first picking. The probable reason for early maturity of primed seed plants may be due to the fact that the plants of primed seeds took fewer days to emerge and flower therefore it matured earlier than the plants of non primed seeds. These results were in agreement with the findings of Harris et al., (2001) who reported that primed crops flower and mature earlier than non-primed in maize. Interaction effects between vigour levels and priming treatments were found to be non significant for days to first picking.

Longer harvest duration is a more desirable trait for continuous supply of fresh bitter gourd fruits to market over longer periods and also avoids market gluts. Harvest duration determines the time period for which the marketable fruits could be harvested so as to meet the market trends. The data revealed the longest harvest duration of 58.27 days in high vigour level $\left(\mathrm{V}_{1}\right)$ and shortest harvest duration of 55.73 days in low vigour level $\left(\mathrm{V}_{2}\right)$. This is on account of early flowering in high vigour seeds as a result of high initial seedling vigour and productivity status of seeds. Early flowering further led to early fruit set thereby leading to longer harvest duration in high vigour seeds. The data recorded longest harvest duration of 58.83 days in seeds primed with Perlite $\left(\mathrm{P}_{2}\right)$. On the other hand Control $\left(\mathrm{P}_{5}\right)$ recorded the shortest harvest duration of 53.33 days. The longer harvest duration may be due to early flowering and subsequently healthier crop growth. Interaction effects between vigour levels and priming treatments were found to be non significant for harvest duration (Table 3).

The yield and yield components viz, fruit yield per plant, fruit yield per plot and fruit yield per hectare differed significantly between high and low vigour seeds. The highest fruit yield per plant, fruit yield per plot and fruit yield per hectare $(1.17 \mathrm{~kg}, 10.38 \mathrm{Kg}$ and 160.77 q) was recorded in high vigour seeds $\left(\mathrm{V}_{1}\right)$ while lowest was observed $(0.75 \mathrm{Kg}, 5.89 \mathrm{Kg}$ and 90.99 q) in low vigour seeds $\left(\mathrm{V}_{2}\right)$, respectively (Table 4). Ghassemi et al., (2010) assessed the effects of seed ageing on field performance of winter oilseed rape cv. Talayeh. Seeds were divided into three sub samples. A sub sample was kept as control or high vigour seed lot. 
The two other sub samples with about $15 \%$ moisture content were artificially aged at $40^{\circ} \mathrm{C}$ for 9 and 12 days. The results concluded that seed ageing can reduce crop yield through decreasing the rate and percentage of seedling emergence. Sudarshan et al., (2006) also reported that plants raised from aged seed lots recorded minimum number of bolls per plant, boll weight and yield per plant as against from fresh seed lot in cotton hybrids.

Increased yield is one of the main objectives of seed priming. Maximum yield per plant, per plot and per hectare $(1.35 \mathrm{Kg}, 12.75 \mathrm{Kg}$ and $196.81 \mathrm{q})$ was observed in seeds primed with Perlite $\left(\mathrm{P}_{2}\right)$. On the other hand, Control $\left(\mathrm{P}_{5}\right)$ recorded minimum $(0.54 \mathrm{Kg}, 3.98 \mathrm{Kg}$ and 61.39q) yield per plant, per plot and per hectare respectively. Interaction effect differed significantly for fruit yield per plant, fruit yield per plot and fruit yield per hectare respectively. High vigour seeds primed with Perlite $\left(\mathrm{V}_{1} \mathrm{P}_{2}\right)$ came out to be the best treatment recording $(1.63 \mathrm{Kg}, 16.22 \mathrm{Kg}$ and $250.35 \mathrm{q})$ fruit yield per plant, per plot and per hectare while its respective Control $\left(\mathrm{V}_{1} \mathrm{P}_{5}\right)$ recorded minimum $(0.85 \mathrm{Kg}$, $6.78 \mathrm{Kg}$ and $104.57 \mathrm{q}$ ) fruit yield per plant, per plot and per hectare. Low vigour seeds also showed the same trend. Low vigour seeds primed with Perlite $\left(\mathrm{V}_{2} \mathrm{P}_{2}\right)$ observed $(1.07 \mathrm{Kg}, 9.28 \mathrm{Kg}$ and $143.26 \mathrm{q})$ fruit yield per plant, per plot and per hectare while its respective Control $\left(\mathrm{V}_{2} \mathrm{P}_{5}\right)$ recorded minimum $(0.22 \mathrm{Kg}$, $1.18 \mathrm{Kg}$ and $18.21 \mathrm{q})$ fruit yield per plant, per plot and per hectare, respectively. An increase of $41 \%$ in high vigour seeds and $77 \%$ in low vigour seeds in fruit yield per ha over Control was recorded in seeds primed with Perlite, respectively. The increase in fruit yield may be due to early emergence, higher total emergence, more number of female flowers per plant, increase in fruit weight and more number of fruits per plant. Pandita et al. (2010) evaluated the effect of solid matrix priming (SMP) alone or in combination with Trichoderma viride or Captan, hydropriming and non-primed seeds for crop performance under optimal and sub-optimal temperatures. The results suggested that SMP in combination with Trichoderma viride improved field emergence by $19 \%$ in conditions of sub-optimal temperatures and by $11 \%$ in optimal temperatures compared with the non-primed control. Final marketable pod yield under sub-optimal temperature was also improved by SMP alone or in combination with Trichoderma viride, but not under optimal temperatures. Hence it was concluded that solid matrix priming in combination with Trichoderma viride can be successfully used to improve seedling emergence and productivity of okra under low temperatures. Mehta et al, (2013) treated the seeds of cucumber cv. K-75 with different solid matrix carriers viz., Cocopeat, Perlite, Vermiculite, Sphagnum moss, Saw dust, Corn cobs, Wheat bran, Bituminous soft coal, Farm Yard Manure (FYM), Vermicompost, Sand,
Forest soil, Azotobacter, Trichoderma viride and Water. The results revealed that solid matrix priming of seed with Cocopeat followed by Perlite gave best results for most of the horticultural traits and for yield and yield contributing characters.

\section{Conclusion}

Both high and low vigour seeds responded well to the osmoticum perlite recording higher values for all the agronomic characteristics studied. However, Low vigour seeds primed with perlite showed greater extent of improvement w.r.t. attributes studied as compared to High vigour seeds primed with perlite. Therefore, from the present studies it can be inferred that seed priming with solid matrix carrier 'Perlite' can be used as a beneficial pre-sowing treatment to enhance the seedling emergence, growth and yield characteristics in bitter gourd.

\section{REFERENCES}

Arif, M. (2005). Seed priming improves emergence, yield and storability of soybean. Ph.D. Thesis in Agronomy, NWFP Agricultural University Peshawar, Pakistan.

Asgedom, H. and Becker, M. (2001). Effect of seed priming with nutrient solutions on germination, seedling growth and weed competitiveness of cereals in Eritrea. In: Proceedings Deutscher Tropentag, 2001, University of Bonn and ATSAF, Magrrat Publisher, Weickersheim, $282 \mathrm{p}$.

Aziza, A., Haben, A. and Becker, M. (2004). Seed priming enhances germination and seedling growth of barley under conditions of Phosphorus and Zinc deficiency. Journal of Plant Nutrition and Soil Science, 167: 630636

Basra, S.M.A., Ahmad N., Khan, M.M., Iqbal N. and Cheema M.A. (2003).Assessment of cotton seed deterioration during accelerated ageing. Seed Science and Technology, 31(3): 531-540

Ghassemi, Golezani K, Aliloo, A.A., Valizadeh, M. and Moghaddam, M. (2008). Effect of hydro and Osmo-Priming on seed germination and Field Emergence of Lentil (Lens culinaris Medik.). Notulae Botanicae Horti Agrobotinici Cluj-Napoca, 36(1): 29-33

Ghassemi, Golezani Kazem, Khomari, Saeid, Dalil Bahareh, Mahootchy, Hosseinzadeh Ayda and Jeddi, Chadordooz Jeddi. (2010). Effects of seed ageing on field performance of winter oilseed rape. Journal of Food, Agriculture \& Environment, 8(1): 175-178

Gomez, K. A. and Gomez, A. A. (1984). Statistical procedure for Agricultural Research, John Wiley, New York, 690p.

Harris, D., Raghuwanshi, B. S., Gangwar, J. S., Singh, S. C., Joshi, K. D., Rashid, A. and Hollington, P. A. (2001). Participatory evaluation by farmers of on-farm seed priming in Wheat in India, Nepal and Pakistan. Experimental Agriculture, 37: 403-415

Hassanpouraghdam, M. B., Emarat, Pardez and Farsad Akhtar, N.(2009). Effect of osmo-priming on germination and seedling growth of Brassica napus L. under salinity conditions. Journal of Food, Agriculture and Environment, 7(2): 620-622 
Mauromicale, G., Cavallaro, V., Stoffella, P. J., Cantliffe, D. J. and Damato, G. (2000). Effects of seed osmopriming on the harvest time and yield of summer squash (Cucurbita pepo L.). $8^{\text {th }}$ International Symposium on timing of field production in vegetable crops, Bari, Italy, 15-18 October,1997. Acta Horticulture, 533: 8388

Mehta, D. K., Thakur, Chetan, Thakur, K. S. and Thakur, Seema. (2013). Effect of solid matrix priming of seed on emergence, growth and yield of cucumber. Green Farming, 4(3): 364-366

Pandita, V. K., and Nagarajan, S. (2004). Effect of pre-sowing treatments in improving emergence of bitter gourd seedlings. Indian Journal of Horticulture, 61(3): 280-281

Pandita, V.K., Anand, A., Nagarajan, S., Seth, R. and Sinha, S.N. (2010). Solid matrix priming improves seed emergence and crop performance in okra. Seed Science and Technology, 38(3): 665-674

Saha,Rani Rina and Sultana, Wahida. (2008). Influence of seed ageing on growth and yield of soyabean. Bangladesh Journal of Botany, 37(1): 21-26

Sandhya Rani, G. M. (2002). Influence of seed treatment with chemicals and botanical on storability and field performance of fresh and aged hybrid cotton seeds. M.Sc.(Agri.) Thesis, University of Agriculture Science, Dharwad.

Sivritepe, N., Sivritepe, H. O. and Eris, A. (2003). Effects of $\mathrm{NaCl}$ priming on salt tolerance in melon seedling grown under saline conditions. Scientia horticulturae, 97: 229-237

Sudarshan, G., Ankaiah, R., Meenakumari, K.V.S., Gopal, Reddy B. and Manohar, Reddy N. (2006). Effect of invigoration treatments of aged seeds on plant growth, development and yield in cotton hybrids. National Seed Seminar, Angrau, Hyderabad, p.49.

Varier, Anuradha, Kuriakose, Vari Alice and Dadlani, Malavika. (2010). The subcellular basis of seed priming. Current Science, 99(4): 450-456

Verma S S, Punia R C and Dahiya O S. 2006. Pre-sowing seed treatment for better crop establishment in mungbean. National Seed Seminar, Abstract XII ANGRAU, Hyderabad. p.145.

Yeh, Y. M. and Sung, J. M. (2008). Priming slows deterioration of artificially aged bittergourd seeds by enhancing anti-oxidative activities. Seed Science and Technology, 